\section{Ordforklaringer}

Lagringsmetoder: Bloddannende stamceller må lagres med et konserveringsmiddel, vanligvis DMSO. Tradisjonelt har $10 \%$ DMSO vært brukt. Avhandlingen viser at $5 \%$ synes optimalt: det gir mindre bivirkninger for pasientene, samtidig som stamcellene holdes levende og aktive under kreftbehandlingen. $5 \%$ DMSO er nå blitt standard lagringsmedium for bloddannende stamceller ved Haukeland universitetssykehus.

Leukaferese: Metode for å skille ut stamceller, eller andre typer hvite blodceller, fra blodet. Ved storvolum leukaferese høstes pasientens blodvolum minst fire ganger.

Cytokiner: Viktige signalmolekyler i immunforsvaret.

\title{
Stamcellebehandling og kreft
}

\author{
Bedre metoder for høsting og lagring av stamceller gir bedre \\ og tryggere behandling for pasienter med beinmargskreft og lymfekreft.
}

Høydose kjemoterapi med stamcelletransplantasjon er viktig i behandling av både beinmargskreft og lymfekreft, men er bare mulig når det høstes tilstrekkelig antall bloddannende stamceller. Knut Liseth har arbeidet med å forbedre metoder for høsting og lagring av stamceller, og for å gjøre stamcellebehandlingen sikrere for pasientene.

- Vi har vist at storvolum leukaferese gir et høyere antall bloddannende stamceller, og at dette er en trygg prosedyre for pasientene.

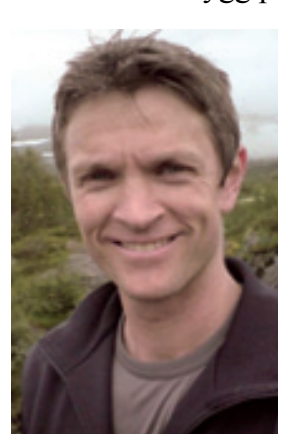

Dette er nå standardprosedyre ved Haukeland universitetssykehus. Sammen med bedre lagringsmetoder, har denne prosedyren også bidratt til at pasienter med beinmargskreft nå høster nok stamceller for to ganger høydosebehandling, Knut Liseth. Foto privat sier Liseth.
Kroppens eget immunforsvar spiller en viktig rolle både når kreftpasienter får vanlig kjemoterapi og ved stamcelletransplantasjon. Liseth har studert hvordan T-celler fungerer under kreftbehandlingen, blant annet ved å se på T-cellenes proliferasjon og utskilling av cytokiner. Han viser at pasientene har et aktivt T-cellesystem allerede for de transplanterte stamcellene begynner å reprodusere - i en periode hvor immunsystemet har lave nivåer av hvite blodceller og det er lavt nivå av blodplater.

Liseth forsvarte avhandlingen Preparation and clinical use of peripheral stem cell grafts. Studies of stem cell harvesting, cryopreservation and immunological aspects of stem cell transplantation for ph.d.-graden ved Universitetet i Bergen 2.10. 2009.

\section{Anne Forus}

anneforu@online.no

Tidsskriftet
Pseudonomas aeruginosa: Bakterie som ofte finnes i fuktige miljøer som jord og vann og som er ufarlig for de fleste, men som kan gi alvorlige infeksjoner hos svekkede pasienter, særlig i intensivavdelinger.

Dent-0-Sept: Munnpensler som ble brukt til munnhygiene og fukting av lepper hos alvorlig syke pasienter.

Se oversikt over doktoravhandlinger i seksjonen Oss imellom på side 2453 skjerpet smittevernrutinene sine. En tredel av pasientene ble ikke smittet direkte fra munnpenslene, men indirekte via sykehuspersonalet, medisinsk utstyr og miljøet. For de mest sårbare pasientene kan nesten apatogene bakterier likevel være sykdomsfremkallende. Da holder det ikke at utstyret er rent, det må være høygradig desinfisert, og helst sterilt, sier han.

Ingen ble stilt strafferettslig ansvarlig for utbruddet, noe Iversen stiller seg svært kritisk til.

- Det strider mot min rettsfølelse, sier han. Iversen disputerte for dr.philos.graden ved Universitetet i Oslo 23.9. 2009. smittevernrutiner

- Produsenten hadde ikke fulgt reglene for kvalitetskontroll av sluttproduktet, og sykehusene, særlig intensivavdelingene, burde hatt strengere kvalitetskontroll ved innkjøp. De burde også

\section{Eline Feiring}

eline.feiring@legeforeningen.no Tidsskriftet 